NBER WORKING PAPER SERIES

\title{
DEBT AND CORPORATE PERFORMANCE: EVIDENCE FROM UNSUCCESSFUL, TAKEOVERS
}

Assem Safieddine

Sheridan Titman

Working Paper 6068

\author{
NATIONAL BUREAU OF ECONOMIC RESEARCH \\ 1050 Massachusetts Avenue \\ Cambridge, MA 02138 \\ June 1997
}

This paper has benefited from presentations at Boston College, Michigan State University, Iowa State University, University of Colorado, University of Texas at Dallas, Rutgers University, the 1997 AFA meetings and the Spring 1997 NBER Corporate Finance meetings. We thank Scott Gibson, Laurie Hodrick, Cliff Holderness, Ed Kane, Robyn McLaughlin, Tim Mech, Tim Opler, Nick Travlos, Gopala Vasudevan, Anil Shivdasani, Rene Stulz, Karen Wruck, Yanfang Yan and an anonymous referee for helpful suggestions on an earlier draft. We are especially indebted to Edith Hotchkiss and William Wilhelm for insightful comments and suggestions. This paper is part of NBER's research program in Corporate Finance. Any opinions expressed are those of the authors and not those of the National Bureau of Economic Research.

(C) 1997 by Assem Safieddine and Sheridan Titman. All rights reserved. Short sections of text, not to exceed two paragraphs, may be quoted without explicit permission provided that full credit, including $(\mathcal{C}$ notice, is given to the source. 
Debt and Corporate Performance: Evidence from

Unsuccessful Takeovers

Assem Safieddine and Sheridan Titman

NBER Working Paper No. 6068

June 1997

JEL Nos. G32, G33, G34

Corporate Finance

\begin{abstract}
This paper examines how debt affects firms following failed takeovers. Using a sample of 573 unsuccessful takeovers, we find that, on average, targets significantly increase their debt levels. Targets that increase their debt levels more than the median amount reduce their levels of capital expenditures, sell off assets, reduce employment, increase focus and increase their operating cash flows. These leverage-increasing targets also realize superior stock price performance over the five years following the failed takeover. In contrast, those firms that increase their leverage the least show insignificant changes in their level of investment and their operating cash flows and realize stock price performance that is no different than their benchmarks. Those failed targets that increase their leverage the least, and fail to get taken over in the future, realize significant negative stock returns following their initial failed takeovers. The evidence is consistent with the hypothesis that debt helps firms remain independent not because it entrenches managers, but because it commits the manager to making the improvements that would be made by potential raiders.
\end{abstract}

Assem Safieddine

Eli Broad Graduate School of Management

Michigan State University

East Lansing, MI 48824
Sheridan Titman

Department of Finance

University of Texas at Austin

Austin, TX 78712-1179 and NBER 


\section{Introduction}

The market for corporate control was quite active and controversial in the 1980s. Although there were many successful takeovers, there were also many takeover attempts that failed. In many of the failed takeovers, the target's management expressed the opinion that the acquirer's offer was insufficient and that the firm was worth more if it remained independent. For example, in our sample of 573 unsuccessful takeover attempts during the 1982-1991 period, 47 targets explicitly announced that they were rejecting the offer because "the price is too low or inadequate." Investors generally greeted these remarks with some skepticism and, as a result, target stock prices generally decreased on the announcement of the termination of a takeover attempt. In our sample of unsuccessful takeover attempts, target stock prices declined, on average, $5.14 \%$ around the date when the termination was announced.

It is often said that "talk is cheap" and that "actions speak louder than words". However, in many cases, target managers combined their cheap talk with meaningful actions. In particular, many of the targets of failed takeovers substantially increased their debt ratios, which can be viewed as either a signal (e.g., Ross (1977)) or a commitment (e.g., Grossman and Hart (1982) or Jensen (1986)) that the promised improvements would in fact take place. In our sample, 207 of the 315 targets which remained independent for at least one year after the initial termination date significantly increased their debt ratio. The median level of total debt scaled by the book value of assets one year before the unsuccessful takeover attempt is $59.8 \%$, and increases on average to $71.5 \%$ one year afterward. ${ }^{1}$

The observed leverage increases following unsuccessful takeovers can be viewed as part of the targets' defensive strategies. Targets of hostile takeover attempts increase debt levels three times as much as their friendly counterparts and leverage increases do in fact reduce the probability that a firm will be taken over in the future. Twenty eight percent of the target firms that increased their debt ratio more than the median between years -1 and +1 were taken over in the five years following the initial failed takeover attempt. In contrast, fifty percent of those target firms that increase their debt ratios less than the median are taken over within five years. ${ }^{2}$

\footnotetext{
${ }^{1}$ Berger, Ofek, and Yermack (1996) report similar evidence for a much smaller sample of Fortune 500 firms. In addition, Denis (1990), using a sample of 37 firms that announced a defensive plan of either a large dividend or a stock repurchase, reports that long-term debt of firms that remain independent after a takeover contest increases from $21.0 \%$ in the pre-contest period to $42.6 \%$ in the post-contest period.

${ }^{2}$ The percentage of firms that remain independent after failed takeovers is substantially higher in our sample than it is in the sample examined by Bradley, Desai and Kim (1983), which examines an earlier time period. Bradley, Desai and Kim (1983) report that 77\% (86 out of 112) of their sample get taken over after 5 years of the initial failed takeover attempt. In contrast, in our later sample only about $48 \%$ (278 out of 573) of
} 
Financial economists have offered two views on how debt might deter unwanted takeovers. As mentioned above, an increase in debt can increase the credibility of the target managers' promises, which in turn increases targets' stock prices, and thus increases the cost of the takeover (see, for example, Zweibel (1996) for a model along these lines). ${ }^{3}$ An alternative view, expressed by Harris and Raviv (1988), Stulz (1988), and Israel (1991), suggests that debt can deter potential acquirers by increasing the cost of the target without improving its value. ${ }^{4}$ In contrast to the first view, this second view does not imply that increased debt, following failed takeovers, should lead to increased performance. ${ }^{5}$

Our empirical evidence supports the view that debt increases deter takeovers because they are associated with performance improvements. In particular, we find that the operating performance of former targets following failed takeover attempts is positively related to the change in the target's debt ratio. This finding continues to hold after controlling for management turnover [documented by Denis and Serrano (1995)], and several other characteristics of unsuccessful takeovers that may explain performance. ${ }^{6}$ We also document that failed targets that increase leverage the most decrease investment, sell off assets, reduce employment, and increase the focus of their firms, which supports the views provided by Jensen (1986).

An analysis of the targets' stock prices reveals that investors partially anticipate the positive effects of debt on the firms' future performances when the takeover attempts are terminated. The cumulative prediction errors (CPE) between five days before the announcement date of a takeover attempt to five days after the termination date is higher for targets which increase leverage than for targets which do not. The positive relationship between leverage changes and stock returns continues to hold when we control for

the failed targets get taken over within five years. The increased percentage of firms that remain independent in the later period is probably due to the increased use of poison pills and other anti-takeover defenses, antitakeover legislation, and perhaps, the deterent effect of debt financing.

${ }^{3}$ See also Stein (1988) which discusses how the possibility of a takeover increases a firm's incentive to signal its value.

${ }^{4}$ The leverage increase makes the target firm more costly to take over in the Harris and Raviv (1988) and Stulz (1988) papers because it increases the percentage ownership of the target's management. In Israel (1991), increased debt deters takeovers that result in wealth transfers to the target's existing debtholders.

${ }^{5}$ These explanations are not necessarily mutually exclusive. Firms might, for example, repurchase shares to increase the cost of a takeover and in doing so, inadvertently commit to a higher output level and lower investment level because of the increased leverage.

${ }^{6}$ For example, we differentiate between bidder-terminated and other rejected takeover attempts because the former conveys more negative information about the target firm than the latter [Dodd (1980)]. We also control for the level of insider ownership, which may proxy for the extent of management's tendency to waste corporate resources [Morck, Shleifer and Vishny (1988)]. After controlling for these and other factors, we still find that the increase in debt is positively related to the improvement in performance of target firms. 
management turnover, whether the takeover attempt was terminated by bidders, whether the offer was hostile or friendly, and whether the target received a subsequent offer.

Although the termination period returns are less negative for those targets that increased leverage the most, they are, nevertheless, still negative. However, our analysis of the long-term performance of these terminated targets suggests that the market underestimated the effect of debt on future performance and that those target managers who increased leverage may have been acting in the interest of shareholders when they terminated the takeovers. In particular, target firms that increased leverage more than the median have higher stock returns in the years following the termination date than a matched sample of firms of similar size, book-to-market and momentum. Indeed, as it turned out, these target shareholders benefited from the termination. In contrast, targets that increase their leverage less than the median significantly underperform their matching benchmarks during this time period.

This paper is organized as follows: Section 2 describes the sample selection procedure and examines the use of debt as a defense against unwanted takeovers. Section 3 examines the investment decisions of firms that increased debt ratios. Section 4 reports the frequency of asset sales, changes in employement and the focusing of operations. Section 5 examines the relation between debt and operating performance following failed takeover attempts. Section 6 examines investors' ability to anticipate the net dominant effect of leverage increase. Section 7 investigates the relation between the long-run stock price performance and leverage. Section 8 includes our findings on time series stock price performance. Section 9 summarizes and concludes the paper.

\section{Sample Description}

\section{II.A Sample Selection}

The sample of unsuccessful takeovers is obtained from W.T. Grimm Mergerstat Review which includes a listing of 721 terminated takeover attempts during the 1982-1991 period. Of these firms, 573 have data available on CompuStat data files. ${ }^{7}$ The W.T. Grimm data set makes no restriction on the fraction of shares sought by bidders. The data set includes the announcement of the transaction, the termination date, the offered price, the premium offered, the means of payment, the names of the target and the bidder, and the reason for the cancellation when available. ${ }^{8}$

\footnotetext{
${ }^{7}$ The 573 target firms have valid data on book value of assets in the year prior to the failed takeover attempt in both research and primary CompuStat data files. Of these, 532 targets have valid debt data in the year prior to the failed takeover attempt year.

${ }^{8}$ In 1988, W.T. Grimm did not report the reason for termination. In these cases, the Wall Street Joumal Index was used instead.
} 
The sample of 573 firms consists of 274 (48\%) NASDAQ-listed targets and $299(52 \%)$ targets listed on NYSE/AMEX. Panel A of table 1 reports the distribution by terminator of the transaction. Twenty nine percent of the cases were terminated by bidders and the remaining $71 \%$ failed for other reasons. ${ }^{9}$ Panel B shows the number of target firms that received subsequent offer(s) after the termination of the original takeover attempt. Within the first year, 187 firms received a second offer (156 of which were successful). By the end of the fifth year more than half the sample received another offer and $278(48 \%)$ of the sample firms were successfully taken over. Panel $\mathrm{C}$ reports the frequency of delisting of sample firms, using CRSP criteria for delisting. These criteria include takeovers, liquidations, bankruptcy filings, insufficient capital, and other infrequent criteria which is grouped into the Other Delisting Category. ${ }^{10,11}$

\section{II.B Summary Statistics}

Table 2 reports summary statistics for sample firms. Leverage is measured as the book value of total debt scaled by the book value of assets. The median leverage ratio increases from 0.598 in year -1 to 0.715 in year +1 after staying virtually constant for the five years prior to year $-1,{ }^{12,13}$ Target debt ratios are about the same as the debt ratios of other firms in their industries in the five years before the takeover attempt. The increase in their debt ratios in year +1 thus puts the target firms at debt ratios substantially above their

9 "Other reasons" includes the $32 \%$ of takeover attempts rejected by targets, $11 \%$ mutually rejected, $20 \%$ with no reason given in either Mergerstat Review or The Wall Street Joumal Index, $1 \%$ due to lack of financing, $13 \%$ due to a higher bid, and $2 \%$ for miscellaneous reasons.

${ }^{10}$ The total number of other delistings is 47 . The reasons for delisting are as follows: no reason available (10), insufficient number of market makers (10), insufficient number of shareholders (2), the price fell below an acceptable level (3), upon company's request with no specific reason given (7), firms went private (4), delinquent in filing (5), and firms did not meet the exchange's financial guidelines for continued listing (6).

${ }^{11}$ According to CRSP, there are only 8 cases where targets filed for bankruptcy. Using Edith Hotchkiss' (1995) sample, we find 21 cases.

${ }_{12}$ The evidence suggests that target firms increase leverage by repurchasing shares. Target firms that increase leverage ratios more than the median change have a significant median decline in the number of shares outstanding of $3.6 \%$ within one year after the failed takeover attempt. Targets that increase leverage ratios less than the median change have zero median change in the number of shares outstanding.

${ }^{13}$ Several issues regarding the leverage increase are worth noting. First, the percentage change in debt is the result of issuing new debt. The median total debt of all sample firms is $\$ 99.53$ million in the year prior to the failed takeover attempt. The median total debt in the year following the takeover attempt is $\$ 130.23$ million. Long-term debt follows a similar pattern. The median long-term debt increases from $\$ 30$ million to $\$ 37.91$ million over the same period. Second, the leverage increase appears to be permanent. The higher leverage ratios remain fairly constant for the five years following year +1 . 
industry counterparts and they stay above their industry counterparts for at least five years after the termination of the takeover attempt. ${ }^{14,15}$

For each firm, annual industry-adjusted performance measures are calculated by subtracting from the target firm's change in performance the change in performance over the same period for the target firm's industry. Industry data is collected from the CompuStat Industrial, Tertiary and Research data files.

Targets in the year prior to the failed takeover attempt have a median (mean) industry-adjusted cash flow to book value of $-0.0015(-0.0096)$. Industry-adjusted cash flow to sales has a median (mean) of $-0.0034(-0.0018)$. Both industry-adjusted cash flow to book value of assets and cash flow to sales, though negative, are not significantly different from zero. The median (mean) market-to-book is 1.21 (1.61) in the year prior to the takeover attempt. To the extent that market-to-book measures investment opportunities, the sample firms have low investment opportunities. Target firms have poor stock price performance in the year prior to the takeover attempt, starting 300 trading days and ending 21 trading days (one month) before the announcement of the takeover attempt. Over this period, the median (mean) of target firms' holding period return minus the holding period return of the value-weighted index is a significant $-4.76 \%(-4.08 \%)$. This evidence is consistent with prior studies that show that target firms are poor performers or poorly managed prior to the takeover attempt.

\section{IIC. Management Turnover Following Failed Takeovers}

Because we are interested in performance changes following unsuccessful takeovers we are also interested in management changes. Several papers examine the link

\footnotetext{
${ }^{14}$ It may be difficult to interpret the changes in debt and cash flows (later) in event time because the sample is changing (532 in year $-1,396$ in year 0 and 328 in year +1 ). For example, leverage ratios increase from year 0 to year +1 . Two possibilities arise: (1) this could be because firms increase their leverage an additional amount, or (2) it is because the firms that drop out between years 0 and +1 are those that have lower leverage ratios. Our findings support the second conjecture. Sixty out of the 68 firms that drop out between years 0 and +1 have a leverage ratio that is lower than the median leverage ratio in year 0 . Given that the composition of our sample is changing from year to year, we compute the change in leverage after restricting our sample to the surviving targets as of year 5 . We find that the median change in leverage from year -1 to years $+1,+2,+3$ is $15.1 \%, 20.6 \%$, and $16.7 \%$ respectively. This compares to a median change of $3.2 \%, 3.09 \%$, and $4.48 \%$ respectively if we impose no restriction on sample firms.

${ }^{15}$ To get further information about the timing of the leverage increase, we utilize the Securities Data Corporation (SDC) Corporate Securities Offerings database which includes a listing of publicly and privately placed debt offerings. However, we were able to identify only 74 debt offerings out of 207 debt offerings by target firms. Out of the 74, 14 offerings occurred within six months before the initial announcement of the takeover attempt. Twenty offerings occurred between the announcement and termination date. On average, there is 76 days between the announcement and termination date. An additional 32 offerings occurred within the first six months after the termination of the takeover attempt. The remaining eight were offered in the second six months after the termination date.
} 
between managerial performance and management turnover in the context of unsuccessful takeovers. Hirshleifer and Thakor (1994), for example, present a model in which boards of directors aggregate their information concerning managerial performance with that of potential acquirers. In their model, unsuccessful takeover attempts are followed by a high rate of management turnover because the takeover attempt conveys adverse information possessed by the bidder about the manager. Jensen and Warner (1988) argue that if acquisition attempts signal poor managerial performance, the presence of well-functioning internal monitoring mechanisms should lead to higher management turnover even if the acquisition attempt is unsuccessful. Furthermore, managers may be dismissed because of value-reducing defensive actions taken during the course of the takeover attempt. These models predict an improvement in the performance of the target firms due to the dismissal of value reducing managers.

Panel B of table 2 reports statistics on management turnover for those companies that remain independent for at least one year. These statistics are based on data from Standard and Poor's Register of Corporations, Directors, and Executives. Management turnover reflects the change in the top executive of the firm, defined as the CEO if there is one and the president otherwise. We compare the CEO in year +1 to the CEO in year -1 , where year 0 is the year of the unsuccessful takeover attempt. If the top executives' names are different then we assume that the firm has experienced turnover in the top management. Denis and Denis (1995) report turnover rates for 1,689 firms covered by the Value Line Investment Survey. For these firms, they document an average turnover rate in top management of $17 \%$ over the average two year period. We document a $32 \%$ turnover for the entire sample, which is much higher than the average turnover rate reported by Denis and Denis. Our figures are very close to the $34 \%$ management turnover documented by Denis and Serrano (1995) for their sample of failed takeovers, but lower than the $44 \%$ turnover rate documented by Aggrawal and Walkling (1994) in the two years following a failed takeover bid.

Management turnover rates are reported separately for firms in two subsamples of our data which consist of failed targets that increase their debt levels less than the median and failed targets that increase their debt levels more than the median. For the first subsample ( $\Delta$ in debt $<$ median $\Delta$ ), $30 \%$ of the top managers were removed, compared to $36.78 \%$ for the second subsample. However, since the difference in these percentages is not statistically significant, we cannot conclude that debt has an appreciable affect on management turnover. We also examine management turnover in the hostile and friendly subsamples. Panel B shows that if the takeover attempt is hostile, $44.10 \%$ of top managers 
are replaced, whereas if the takeover attempt is friendly, only $29.17 \%$ are replaced. The difference in these percentages is significant at the $5 \%$ level.

\section{II.D. Debt as a Takeover Defense}

If target firms use debt to defend against unwanted takeovers then there should be a difference in the change in debt levels between friendly and hostile takeovers. Table 3 reports the percentage change in total debt scaled by the book value of assets for the two subsamples consisting of friendly and hostile takeovers. For the friendly takeover group the median percentage change in the leverage ratio from one year prior, to one, two and three years following the failed takeover attempt is $2.07 \%, 2.45 \%$, and $4.09 \%$ respectively. For the hostile group, the median total debt increase amounts to $12.24 \%$, $8.97 \%$, and $7.59 \%$ over the same period. ${ }^{16}$ We find that the difference between these percentage changes in each of the three years following the failed takeover attempt is statistically significant using the Mann-Whitney-Wilcoxon test.

Some managers may decide not to increase leverage because they are able to use other defensive mechanisms to deter the acquisition. We investigate this issue by looking at a wide variety of defensive tactics which include stock lockup, white knight, white squire, greenmail, pacman, scorched earth, and self tender. In our sample, there are 108 cases where targets did not increase their leverage. Fifty eight firms (comprising $18 \%$ of firms that remain independent after the first year) adopted a defensive tactic other than debt. The table below reports the frequency of cases where targets have used a defensive tactic in the two groups: targets that increased leverage and targets that did not. This table shows that targets that increase their leverage are less likely to adopt other defensive tactics to defeat the takeover attempt.

No defensive tactic

\begin{tabular}{|c|c|}
\hline$\Delta$ in debt $>0$ & $\Delta$ in debt $<0$ \\
\hline $\begin{array}{c}174 \\
33 \\
207\end{array}$ & $\begin{array}{c}50 \\
58 \\
108\end{array}$ \\
\hline
\end{tabular}
Total

${ }^{16}$ The total number of observations in the analysis differs from year to year because of data availability. For example, table 2 reports that there are 532 targets with valid debt data in year -1 . Over the first 12 months following the termination of the failed takeover attempt $188(156+3+1+4+24)$ firms were delisted as reported in table 1. Table 3 reports 90 and 238 debt observations for the hostile and friendly group respectively. The difference between 532 and 188 is 344 , and the sum of 90 and 238 is 328 . In table 3, year +1 denotes the end of the first fiscal year after the termination of the takeover attempt, it does not necessarily mean 12 months after the termination. Take for example a takeover attempt that was terminated in March, and this target firm has a December fiscal year end. We are measuring whether it was delisted on CRSP from March through February of the following year (12 months period-panel $C$ of table 1$)$. In the analysis using CompuStat data, year +1 means the end of the following fiscal year, i.e., December, not February, of the following year. 


\section{Changes in Debt and Investment Choices}

Our hypothesis is that debt financing will induce failed targets to make changes that improve their operating performance and as a result boost their stock price. We will first look explicitly at the kind of changes made by failed targets. We will then examine the extent to which these changes lead to operating improvements and higher stock prices.

As discussed in Myers (1977), increased debt can have the effect of decreasing a firm's investment expenditures. Thus, as Jensen (1986) explains, if managers have a tendency to overinvest, increased debt can have the effect of reducing their level of investment to what might approximate the value-maximizing level. This would provide an additional explanation for why debt improves value and thereby deters takeovers.

Although we are unable to determine whether target firms are over- or underinvesting, we can document whether investment expenditures increase or decrease after the takeover attempts and can compare how these changes relate to changes in leverage. To investigate this issue we examine capital expenditures and research and development expenses for the seven years around the failed takeover attempts. Panel B of Table 4 indicates that the median (mean) capital expenditures scaled by the book value of assets of target firms that increase their leverage more than the median in year -1 is $0.067(0.086){ }^{17}$ Capital expenditures scaled by book value of assets in year +2 for these firms has a median (mean) of $0.048(0.050)$ which represents a median (mean) percentage reduction of $35.36 \%(12.16 \%)$ from one year prior to two years after the takeover attempt. ${ }^{18}$ Research and development expenditures shows a similar decline for the leverage increasing targets, however, the decline is not significant at conventional levels. Target firms that increase their leverage less than the median have an insignificant change in their capital and research and development expenditures.

It should be noted that although the negative correlation between the change in investment expenditures and the change in leverage is consistent with the Myers (1977) and Jensen (1986) models, the results do not support the Ross (1977) signaling model which suggests that those managers that are the most optimistic about future productivity increase leverage. We would expect, holding all else equal, that those managers who are the most optimistic about future prospects will increase investment expenditures as well as increase leverage which is not what we observe.

\footnotetext{
${ }^{17}$ Results are qualitatively identical when we scale capital expenditures and research and development expense by sales rather than book value of assets.

18 This reduction is significant at the $1 \%$ level.
} 


\section{Corporate Restructuring}

Several studies argue that external takeover threats play a pivotal role in the restructuring of public firms. Bhagat, Shleifer, and Vishny (1990) and Berger and Ofek (1996) document that successfully acquired firms usually undergo an extensive restructuring involving asset sales and layoffs. In addition, Berger and Ofek (1996), and Denis, Denis and Sarin (1996) argue that firms that implement corporate refocusing programs often do so in the presence of external control pressures such as takeover threats.

Panel E of Table 4 reports that failed targets that increase leverage show similar tendencies to restructure and downsize. Specifically, we examine the percentage of firms that sell off assets, changes in employment, and changes in the number of reported SIC codes during the two years following a failed takeover attempt. In each case, we compare the changes in subsamples stratified by the firms' change in leverage.

We found that $45.5 \%$ of those targets that increased leverage more than the median had asset sales reported in the Wall Street Joumal in the two years following the failed takeover. In contrast, only $16.5 \%$ of those targets that increased leverage less than the median had asset sales reported (these percentages are statistically different). ${ }^{19}$ In addition, failed targets that increase leverage more than the median amount reduce their labor force more than targets that increase leverage less than the median amount (difference is significant at the 5\% level). Those targets that increased leverage the most decreased employment by more than $5 \%$ while those targets that increased leverage the least did not change employment significantly.

Failed targets that increased leverage more than the median increased focus, as indicated by the number of SIC codes reported in Dun and Bradstreet Industrial Codes. Panel E of Table 4, which reports the change in the average number of reported SIC codes per firm from one year before the takeover attempt to 5 years after, shows that targets that increase leverage less than the median report that they do business in 0.156 more SIC codes following the failed takeover. In contrast, failed targets that increase leverage more than the median do business in 0.645 less SIC codes. Similar to asset sales, the difference in the change in the number of SIC codes is statistically significant ( $p$-value $=0.002$ ).

\footnotetext{
${ }^{19}$ Lang, Poulsen, and Stulz (1995), and John and Ofek (1995) are among several studies that report positive stock price reaction to asset sale announcements. John and Ofek (1995) also report operational improvements in the three years following asset sales.
} 


\section{Changes in Debt and Operating Performance}

\section{V.A. Univariate Analysis}

The previous section documented that failed targets that increase their leverage make a number of changes that can potentially improve their cash flows. This section examines changes in the firms' cash flows directly.

We begin the investigation of this issue by examining the operating performance of targets of unsuccessful takeover attempts based on their pretax operating cash flow. ${ }^{20}$ Cash flow is scaled by book value of assets to allow comparison across firms and through time. ${ }^{21}$ We also scale cash flow by sales in order to minimize the effects of restructuring through asset sales, which are commonly used to fight unwanted takeovers. ${ }^{22}$ We measure the percentage change in these cash flow variables in the first five years after the termination date (years +1 through +5 ) relative to the year prior to the takeover attempt. ${ }^{23}$ Industry-adjusted performance measures are calculated by subtracting for each firm the industry median performance, where the industry median is measured using all firms on CompuStat with the same two-digit SIC code. ${ }^{24}$

By looking at cash flows over a five year period, we are able to capture both long and short-run effects of the debt changes. It is important to examine cash flows over a long time period since increased debt can make firms more short-sighted in their operating and

${ }^{20}$ This measure of operating performance has been used in previous studies by Ravenscraft and Scherer (1987), Kaplan (1989), and Smith(1990). Pretax operating cash flow is measured as net sales, less cost of goods sold, less selling and administrative expenses, before deducting depreciation and amortization expense. We focus on pretax operating cash flows which are unaffected by changes in tax status or capital structure.

${ }^{21}$ We scale by book value of assets rather than market values because, conceptually, market values impound valuations of differences in firm and management quality.

${ }^{22}$ Alternatively, scaling cash flows by the market value of the firm in year -1 gives qualitatively identical results.

${ }^{23}$ Industry-adjusted percentage change is calculated as follows:

$\left[\frac{C F B V_{j}-C F B V_{i}}{\left|C F B V_{i}\right|}\right]-\left[\frac{C F B V I_{j}-C F B V I_{i}}{\left|C F B V I_{i}\right|}\right]$, where $C F B V_{\mathrm{j}}$ is the cash flow to book value in year $\mathrm{j}$,

and $\mathrm{CFBVI}_{\mathrm{i}}$ is the median cash flow to book value of assets of the firms' two-digit sic code industry in year i. The absolute value of the denominator is used to mitigate the effect of negative cash flows. An additional problem that might arise from the use of percentage changes is the possibility that cash flows scaled by the book value of assets in year -1 might be close to zero which may result in (close) to infinite percentage change. We obtain qualitatively identical results when raw changes rather than percentage changes are computed.

${ }^{24}$ Barber and Lyon (1997) show that test statistics are biased when sample firms exhibit unusual performance prior to an event. They suggest employing a performance-based matching procedure for selecting control firms. Since operating performance measures like industry-adjusted cash flow to book 
investment decisions, making immediate cash flows higher at the expense of later cash flows. For example, Maksimovic and Titman (1991) argue that debt may distort firms' incentives to offer high quality products, boosting short-run profits by cutting costs at the expense of their long-term reputations and profits. ${ }^{25}$ In addition, managers may have incentives to manipulate their earnings following a failed takeover attempt and these incentives may differ depending on the firm's leverage ratio. ${ }^{2.6}$ If short-term operating income increases because of short-sighted incentives or if firms manipulate their accounting numbers, we should expect reported operating income to decline in the long run.

Since cash flow measures are skewed, we present results for medians as well as means and report significance levels based on a two-tailed sign test. ${ }^{27}$ The null hypothesis is that post-termination cash flows equal pre-termination cash flows. In order to examine the relation between leverage and performance, we split the sample into two groups based on the median change in leverage between year -1 and year +1 .

Table 5 documents that those target firms that increased their leverage the least showed reductions in their industry-adjusted operating profits while those that increased their leverage the most showed increases in their industry-adjusted operating profits. Specifically, panel A shows that cash flows for those targets, where the change in total debt is lower than the median change, significantly decline relative to the year prior to the termination of the takeover attempt. The industry-adjusted percentage change in cash flow/book value of assets relative to year -1 has a median of $-6.58 \%,-16.69 \%$, and $-24.42 \%$ in each of the first three years following the failed attempt. When cash flows are scaled by sales or by market value in year -1 , the results are qualitatively similar. Panel B reports the same operating performance measures for targets where the change in total debt is higher than the median change. The industry-adjusted percentage change in cash flow scaled by market value in year -1 increases by $10.04 \%, 14.86 \%$, and $25.68 \%$ in the first three years following the failed takeover attempt.

\section{V.B Multivariate Analysis}

Up to this point we have established that leverage increases are associated with asset sales, reductions in capital expenditures, increased focus and reductions in employments. We have also established that leverage increases are associated with

\footnotetext{
value and cash flow to sales are insignificantly different from zero, we simply use industry comparisons rather than a performance-based matching procedure.

${ }^{25}$ Rose (1988) finds evidence that the safety records of airlines decline after they get into financial difficulties.

${ }^{26}$ For example, see Teoh, Welch, and Wong (1995).

${ }^{27}$ When we trim a few outliers, the means and medians are very similar.
} 
improvements in cash flows. It is likely that some of the observed increase in cash flows is due to cuts in wasteful investment, sales of underperforming assets, and the reductions in employment. However, it is also possible that there are improvements in cash flows that come about because of unobserved incentive improvements that are also associated with increased leverage. To investigate this possibility, we estimate multivariate regressions which examine the effect of leverage changes on cash flow changes after controlling for these and other factors.

The variables included in this regression include a dummy variable for management turnover, a dummy variable taking the value of 1 if the company sells an asset in the year of or the year after the failed takeover attempt and zero otherwise, the change in the number of SIC codes from one year before to five years following the takeover attempt, a dummy variable for whether the takeover attempt was terminated by the bidder or the target, a dummy variable for whether or not the takeover attempt was hostile, and the level of insider ownership. $^{28}$ We expect that performance is likely to improve the most for those targets with new managers and for those offers that were hostile. In addition, we hypothesize that bidder-terminated takeover offers reveal more negative information about the target firm than other terminated offers. ${ }^{29}$

Our cross-sectional models are as follows:

$\Delta$ in PERFORMANCE $=f(\Delta$ in LEVERAGE, ASSET SALES, $\Delta$ in \# of SIC CODES, CEO TURNOVER, $\% \Delta$ in \# of EMPLOYEES, $\% \Delta$ in CAPITAL EXPENDITURES, HOSTILEBID, INSIDER OWNERSHIP, BIDDER-TERMINATED,)

where industry-adjusted cash flow to sales and industry-adjusted cash flow to assets are used as proxies for performance. Tables 6 and 7 report the results of these cross-sectional regressions.

The cross-sectional regressions indicate that the change in leverage has a significant effect on cash flows even after accounting for the other variables. This is especially true

\footnotetext{
${ }^{28}$ All results are robust to alternative specifications of the ownership variable. One alternative specification that we examined is the piecewise regression by Morck, Shleifer, and Vishny (1988).

${ }^{29}$ Asquith (1983) analyzes the abnormal stock price performance of firms that engage in merger bids. He documents a $-6.40 \%$ return for unsuccessful target firms on the termination date. He interprets this finding to indicate that termination of the merger attempt conveys negative information. We measure the cumulative prediction errors (CPE) for the termination period using the market model over a seven-day window, $(-5,1)$. We estimate the beta of the firm using 100 trading days of data (day -199 to -99 relative to the announcement of the transaction) and use the CRSP value-weighted index as the market index. When the bidder terminates the transaction, the CPE are $-8.42 \%$ compared to $-3.14 \%$ for other-rejected transactions (not reported). The difference in the means is statistically significant using parametric and nonparametric tests at the $1 \%$ level.
} 
when we examine long run changes in cash flow (e.g., from year -1 to year +5 ), where the effect of the leverage change on cash flows is quite strong. Another variable that affects long-term cash flows is CEO turnover, consistent with Denis and Serrano (1995), cash flows improve more for firms that get new CEOs. However, cash flows do not seem to benefit in the short-run from getting a new CEO. Perhaps, this reflects the fact that firms that show quick improvements following a failed takeover offer are less likely to replace their CEOs.

We were surprised to find that the other variables had virtually no marginal explanatory power in the long term regressions. Perhaps this is because changes in employment, asset sales, and the scaling back in employment is a mixed signal; firms benefit from cutting back waste, but they are less likely to take these actions if they believe that their businesses are improving. Leverage increases, on the other hand, simultaneously signal that firms have the intentions of cutting waste and that they are optimistic about the firm's prospects. ${ }^{30}$

\section{Are the Positive Effects of Debt Anticipated?}

To examine whether the effect of debt on performance is anticipated, we examine the stock returns of the failed targets in the period around the termination date as well as the longer period between the initial announcement of the proposed takeover and the termination date. As mentioned in the introduction, target stock prices drop on the termination announcement. However, consistent with earlier studies by Bradley (1980) and Dodd (1980), the target stock prices do not fall to the levels observed prior to the initial takeover announcement.

Target stock prices fall significantly less on the termination announcement for those firms that increase leverage more than the median, suggesting that investors at least partially anticipate the debt increase as well as the positive effects of debt on performance. ${ }^{31}$ Specifically, targets that increase leverage more than the median have mean cumulative prediction errors (CPE) from 5 days before the termination announcement until 1 day after the termination day of $-2.7 \%$. This compares to $-7.8 \%$ for targets that increase leverage less than the median. The difference between the two means is significant at conventional levels. In addition, target firms that increase leverage more than the median have a mean

${ }^{30}$ We replicate tables $6 \& 7$ with the difference in buy-and-hold returns between the targets and their matching benchmarks from the termination month to the earlier of five years or the delisting date as the dependent variable. Consistent with tables $6 \& 7$, we find leverage and management turnover to be the only variables with significant coefficients. 
(median) CPE during the announcement-termination period of $13.2 \%(11.5 \%)$ which is significantly higher than the $6.1 \%(5.6 \%)$ return of target firms that increase leverage less than the median.

To test whether other factors that are correlated with the leverage change also influence stock returns over this time period we ran a series of multivariate regressions which are reported in Table 8. In the univariate regression, Model 1, the coefficient of the change in leverage is positive and significant. In Models 2 through 5, which control for changes in the top management, whether or not the offer was terminated by the bidder, whether the takeover attempt was hostile or not, and whether a subsequent offer is made, the coefficient of the leverage change is still significantly positive.

\section{Debt and Post-Termination Stock Price Performance}

In this section we examine the long-run performance of firms following the termination of takeover offers. We have two motivations for examining the long-run returns. First, we are interested in looking in more detail at whether the improvements described in previous sections translated into gains to shareholders. Our event study evidence suggests that at the time of the termination announcement, the terminated targets that increased leverage the most suffered less losses. However, since the difference in stock returns between the two samples are small relative to the improvements subsequently realized by the firms that increased leverage more than the median, we have reason to believe that the stock price reaction on the termination announcement did not fully anticipate these improvements. Our second motivation has to do with the question raised in the introduction regarding whether the target's management acted in the shareholders interests when they turned down the takeover offer. In most cases, the immediate stock price reaction to the termination suggested that investors did not believe that the managers of the terminated targets were acting in their shareholders' interests. However, a complete evaluation of the managers' choices requires that we examine the long term consequences of their decisions.

\section{VII.A Long-Run Performance}

In order to examine the long-run stock price performance of target firms we follow each firm from the termination month until the earlier of: the delisting month, the attempt's fifth anniversary month, or December, 1994. For every target, the buy-and-hold return is calculated over 60 months, starting from the termination month of the takeover attempt to

\footnotetext{
${ }^{31}$ Most of the large debt offerings take place following the termination announcement. However, targets sometimes make statements like "negotiating with our bank to extend a credit line" or "the new
} 
the closing price five years afterwards. If a target firm is delisted prior to its anniversary month, we truncate its total return on that month. Thus the percentage buy-and-hold return for firm $i$ is

$$
R_{i T}=\left[\prod_{t=+5}^{\min [. \text { deliss }]}\left(1+r_{i t}\right)-1\right] \times 100 \%
$$

where +1 stands for one month after the termination month of the takeover attempt, $\min [\mathrm{T}$, delist] is the earlier of the last month of CRSP-listed trading or the end of the three- or fiveyear window, and $r_{i t}$ is the return for firm $i$ on month $t$.

For the purpose of comparison, each target firm is matched with a benchmark portfolio consisting of stocks in the same size quintile, the same book-to-market quintile, and the same momentum quintile as the target in the year before the event. ${ }^{32}$ The composition of this portfolio is updated yearly to reflect changes in the target's characteristics. However, since we are simply rolling over the returns from this strategy without adding or subtracting money from the benchmark, over time the values of the benchmark and the target will diverge as their cummulative returns will diverge.

Table 9, panel A reports the buy-and-hold long-run returns for the sample of target firms. For the entire sample, the buy-and-hold returns of targets over the five year period has a mean (median) of $38.18 \%$ (22.82\%). The long-run buy-and-hold return for their matching benchmarks has a mean (median) of $35.85 \%$ (29.05\%). The difference between the buy-and-hold returns of the targets and their benchmarks has a mean (median) of $2.33 \%(0.64 \%)$.

In order to examine the effect of debt on the long-run stock price performance, we separately examine the long term post-termination performance of targets with leverage changes above and below the median change. In panel B, the mean (median) benchmarkadjusted buy-and-hold retum for targets with a change in leverage less than the median change is $-14.16 \%(-24.07 \%)$. Panel C reports the long term post-termination performance of targets which increase leverage more than the median change. For this group, the mean (median) benchmark-adjusted buy-and-hold returns is $19.10 \%$ (13.72\%).

One might conjecture that the higher long-run returns of the more levered targets are due to their having higher betas (see Hamada (1972)). However, this does not appear to be

restructuring plan includes raising a certain amount of short-term debt" prior to the termination.

${ }^{32}$ These are the benchmark portfolios used by Daniel, Grinblatt, Titman, and Wermers (1997) to evaluate mutual funds. 
the case. We measure beta for both groups over the five year period under analysis. The mean (median) beta for targets which increase leverage more than the median change is 1.019 ( 1.023 ), which compares to 1.005 (1.003) for targets which increase leverage less than the median change. Perhaps the reduction in investment by the leverage increasing firms reduces risk and thereby offsets the effect of leverage on their stocks' betas. In any event, we do not believe that it is differences in systematic risk that drive these differences in return.

One might also question whether we can conclude that investors underreacted to the leverage increase, when in many cases, investors did not know about the leverage increase until many months after the takeover was terminated. To address this issue, we examine buy and hold returns of terminated targets from one year after the termination date, when the leverage change was definitely known, until five years after the termination date. We again find that the targets that increase their leverage more than the median outperform their benchmarks, in this case by $18.26 \%$ on average. In contrast, those terminated targets that increased leverage less than the median realized stock returns in this time period that underperformed their benchmarks by $12.25 \%$ on average. These results suggest that most of the excess returns associated with the leverage change following the termination date occurred subsequent to when the leverage change was known.

\section{VII.B Time-series analysis}

The evidence presented in the previous subsection indicates that terminated targets that increase leverage more than the median perform considerably better than their characteristic-matched benchmarks. However, because of the difficulties associated with evaluating the statistical significance of long-term performance, we did not attempt to estimate whether the benchmark-adjusted long-term returns were statistically significant. ${ }^{33}$

\footnotetext{
${ }^{33}$ See for example, Barber and Lyon (1997), Kothari and Warner (1996) and Brav (1997).
} 
To examine whether the excess returns of the leverage increasing targets are statistically significant we perform a time-series analysis of an "investment portfolio" trading strategy. The trading strategy consists of forming separate portfolios of target firms and their matched counterparts over the entire period of the sample (January 1982 through December 1994). Each target firm is added to the target portfolio in the month following the termination of the failed takeover attempt and is kept in the portfolio for sixty months or until the firm ceases trading, whichever comes first.

As we did in the last subsection, a characteristic-matched benchmark portfolio is formed for each target firm and these portfolios are then combined into a larger portfolio that mimics the characteristics of the target portfolio described above. The average monthly returns of this benchmark portfolio is then compared to the average monthly returns of the target portfolio returns. Assuming that the time-series of returns are independently and identically distributed allows us to test whether these monthly averages are reliably different.

Panel A of Table 10 reports the mean monthly returns for portfolios of targets that change their leverage more than the median change. The results confirm the earlier finding that target firms that increase their leverage more than the median change outperform their matching counterparts. The monthly average difference between these target firms and their matching counterparts is $+0.516 \%$, which is significant at the $10 \%$ level. On the other hand, Panel B shows that target firms with changes in leverage that are below the median change have slightly lower returns than their matching counterparts.

\section{VII.C Bradley, Desai, and Kim (1983) Revisited}

Bradley (1980) and Dodd (1980) observed that when takeover offers are withdrawn, target stock prices fall, but they do not fall to their level prior to the takeover. There have been two proposed explanations for this observation, which is also found in our data. The first explanation is that the original offer reveals favorable information about the target as a stand alone entity. The second explanation is that many failed targets, once put into play, eventually get taken over. Our results suggest a third explanation for why the stock prices of failed targets generally stay above their pre-offer levels. Some of the failed targets, in particular those that increase leverage, make many of the improvements that would have been made by the bidder. Bradley, Desai, and Kim (1983) provide evidence supporting the second explanation. They report that target firms that receive subsequent offer(s) retain most of their gains made at the initial announcement. However, targets that 
do not receive any subsequent offer lose all the gains in the two years following the initial offer.

Our sample is different from the Bradley, Desai, and Kim sample in two important respects. First, as we mentioned in the introduction, a larger percentage of our failed targets remain independent and this is especially true in the sample of firms that increase leverage the most. Second, we do not find that failed targets that remain independent perform poorly on average. In fact, those target firms that increase their leverage outperform their matching counterparts by $41.16 \%$ (median $=29.73 \%$ ) over the following 5 years. For targets that do not increase their leverage, the mean difference is $-24.62 \%$ (median $=-19.4 \%$ ) suggesting that these failed targets perform. very much like the failed targets in the Bradley, Desai, and Kim sample.

\section{Summary and Conclusions}

This paper examines the use of debt by takeover targets and its subsequent effect on corporate performance. Our results suggest that debt reduces the probability of a firm being taken over because it commits the target's manager to make the improvements that would have been made by a potential raider. Specifically, we find that those firms that have the largest increase in debt following a failed takeover reduce their levels of capital expenditures, sell off assets, reduce employment, increase focus and increase their operating cash flows. These leverage-increasing targets also realize superior stock price performance over the five years following the failed takeover. In contrast, those firms that increase their leverage the least show insignificant changes in their level of investment and their operating cash flows and realize stock price performance that is no different than their benchmarks. Those failed targets that increase their leverage the least, and fail to get taken over in the future, realize significant negative stock returns following their initial failed takeovers.

Our evidence suggests that investors anticipate the positive effects associated with the higher leverage, but not fully. During the period between the initial takeover announcement and the termination announcement the stock price performance is significantly less negative for those failed targets that increase leverage the most. This suggests that investors anticipate that the more highly levered firms are likely to implement some of the changes that would be made by the bidder. In addition, the stock prices of the

leverage increasing targets outperform their benchmarks for five years following the 
termination which suggests that investors initially underestimate the extent to which firm value will be improved. ${ }^{34}$

These results are consistent with earlier evidence that showed that the operating performance of firms improves following leveraging-increasing recapitalizations [Kaplan (1989), Smith (1990), and Denis and Denis (1993)]. Although the authors of these earlier studies also provide incentive-based explanations for their results, some have argued [e.g., Lowenstein (1985)] that the productivity improvements following LBOs and leveraged recapitalizations could be due to the fact that managers, possessing private information, had incentives to initiate these transactions when productivity would have improved anyway. ${ }^{35}$ Since the initiation and timing of the takeover attempt is not under the discretion of target management, it is less likely that managers of target firms are timing the leverage increase to coincide with favorable private information. ${ }^{36}$ In addition, failed takeovers provide a cleaner test of the incentive effects of debt since they generally are not accompanied by the changes in the governance structure that occurs with LBOs. Hence, our results provide important evidence about the relation between debt and productivity in general, as well as on the use of debt as a takeover defense.

\footnotetext{
${ }^{34}$ The fact that market prices seem to underreact to the leverage increases is consistent with the evidence in a number of recent studies including Loughran and Ritter (1995), Lakonishok and Vermealen (1990) and Michealy, Thaler and Womack (1995).

${ }^{35}$ Kaplan (1989) and Smith (1990) recognize this potential information bias and provide indirect evidence suggesting that superior management information is unlikely to account for the observed gains from management buyouts. First, Kaplan compares the pre-buyout financial projections managers give to shareholders with the actual post-buyout realizations. He finds no evidence that the projections are low. He also finds that management turnover at the time of the buyout is unusually high. He concludes that none of the above findings support the "managers' private information" hypothesis. Smith finds that operating returns do not increase after the failed management buyout attempts. She also finds that whether management initiated the MBO or not is not a factor in the post-buyout performance.

${ }^{36}$ Other characteristics of highly leveraged transactions besides the increase in leverage may lead to improvements in performance. LBOs, for example, are characterized by increased ownership concentration, which may give managers an additional incentive to work to increase firm value. Furthermore, LBO sponsors provide monitoring services, which may contribute to managerial discipline and thus improve cash flow performance. Therefore, in the analyses of highly leveraged transactions, it is difficult to distinguish the effect of debt from the effects of timing (which is under managers' discretion), monitoring by the LBO sponsor, and increased ownership concentration.
} 


\section{References}

Aggrawal, A., and R. Walkling, 1994, Executive careers and compensation surrounding takeover bids, Journal of Finance 49, 985-1014.

Asquith K.P., 1983, Merger bids, market uncertainty, and stockholder returns, Journal of Financial Economics 11, 162-182.

Barber, B., and J. Lyon, 1997, Detecting long-run abnormal stock returns: The empirical power and specification of test-statistics, Journal of Financial Economics, forthcoming.

Berger, P., and E. Ofek, 1996, Causes and consequences of corporate refocusing programs, working paper, New York University.

Berger, P., G., E. Ofek, and D. Yermack, 1996, Managerial entrenchment and capital structure, working paper, New York University.

Bhagat, S., A. Shleifer, and R. Vishny, 1990, Hostile takeovers in the 1980s: The return to corporate specialization, Brookings papers on economic activity: Microeconomics, 1-72.

Bradley, M., A. Desai, and E. H. Kim, 1983, The rationale behind interfirm tender offers: information or synergy?, Journal of Financial Economics 11, 183-206.

Bradley, M., 1980, Interfirm tender offers and the market for corporate control, Journal of Business, October 1980, 345-376.

Brav, A., 1997, Inference in long-horizon event studies: A parametric-bootstrap approach, working paper, University of Chicago.

Daniel, K., M. Grinblatt, S. Titman, and R. Wermers, 1997, Measuring fund performance with characteristic based benchmarks, Journal of Finance, forthcoming.

Denis, D., 1990, Defensive changes in corporate payout policy: share repurchases and special dividends, Journal of Finance 45, 1433-1456.

Denis, D. J. and D. K. Denis, 1993, Managerial discretion, organizational structure, and corporate performance: a study of leveraged recapitalization, Journal of Accounting and Economics 16, 209-236.

Denis, D. J., D. K. Denis, and A. Sarin, 1996, Agency problems, equity ownership, and corporate diversification, Journal of Finance, forthcoming.

Denis, D. J. and D. K. Denis, 1995, Performance changes following top management dismissals, Journal of Finance 50, 1029-1057.

Denis, D., and J. Serrano, Active investors and management turnover following unsuccessful control contests, 1995, working paper, Virginia Tech.

Dodd, P., Mergers proposals, management discretion, and shareholder wealth, Journal of Financial Economics, June 1980, 105-137.

Franks, J., R. Harris, and S. Titman, 1991, The post-merger share price performance of acquiring firms, Journal of Financial Economics 29, 81-96. 
Grossman, S., and Oliver Hart, 1982, Corporate financial structure and managerial incentives, in J. McCall, ed.: The Economics of Information and Uncertainty (University of Chicago Press, Chicago).

Hamada, R.S., 1972, The effect of the firm's capital structure on the systematic risk of common stocks, Journal of Finance 27, 435-452.

Harris, M. and A. Raviv, 1988, Corporate control contests and capital structure, Journal of Financial Economics 20, 55-86.

Hirshleifer, D., and A. Thakor, 1994, Managerial performance, board of directors and takeover bidding. Journal of Corporate Finance 1, 63-90.

Hotchkiss, E., 1995, Post-bankruptcy performance and management turnover, Journal of Finance 50, 3-21.

Israel R., 1991, Capital structure and the market for corporate control: The defensive role of debt financing, Journal of Finance 46, 1391-1409.

Jensen M., C. 1986, Agency costs of free cash flow, corporate finance and takeovers, American Economic Review 76, 323-329.

Jensen, M. C. and J. Warner, 1988, The distribution of power among corporate managers, shareholders, and directors, Journal of Financial Economics 20, 3-24.

John, K. and E. Ofek, 1995, Asset sales and increase in focus, Journal of Financial Economics 37, 105-126.

Kaplan, S. 1989, The effects of management buyouts on operating performance and value, Journal of Financial Economics 24, 217-254.

Kothari, S. P., and J. Warner, 1996, Measuring long-horizon security price performance, Journal of Financial Economics, forthcoming.

Lakonishok, J., and T. Vermaelen, 1990, Anomalous price behavior around repurchase tender offers, Journal of Finance 45, 455-478.

Lang, L., A. Poulson, and Rene Stulz, 1995, Asset sales, firm performance, and the agency costs of managerial discretion, Journal of Financial Economics 37, 3-37.

Loughran, T., and J. Ritter, 1995, The new issues puzzle, Journal of Finance 50, 23-51.

Lowenstein, L., 1985, Management buyouts, Columbia Law Review 85, 730-784.

Maksimovic, V., and S. Titman, 1991, Financial policy and reputation for product quality, Review of Financial Studies, 4, 175-199.

Michaely R., R. Thaler and K. Womack, 1995, Price reactions to dividend initiations and omissions: overreaction or drift?, Journal of Finance 50, 573-608.

Morck, R., A. Shleifer, and R. Vishny, 1988, Management ownership and market valuation: An empirical analysis, Journal of Financial Economics 20, 293-316. 
Myers, S., C., 1977, Determinants of corporate borrowing, Journal of Financial Economics 5, 147-175.

Ravenscraft, D. and F. M. Scherer, 1987, Mergers, selloffs and economic efficiency (The Brookings Institution, Washington, DC).

Rose, N., 1988, Profitability and product quality: financial indicators and airline accident performance, working paper, MIT Sloan School of Management.

Ross, S., 1977, The determination of financial structure: The incentive-signaling approach, Bell Journal of Economics, 8, 23-40.

Smith, A., 1990, Corporate ownership structure and performance: the case of management buyouts, Journal of Financial Economics 27, 143-164.

Stein, J. C., 1988, Takeover threats and managerial myopia, Journal of Political Economy, 61-80.

Stulz, R. M., 1988, Managerial control of voting rights: financing policies and the market of corporate control, Journal of Financial Economics 20, 25-54.

Stulz, R. M., 1990, Managerial discretion and optimal financing policies, Journal of Financial Economics 26, 3-28.

Teoh, S. H., I. Welch and T. J. Wong, 1995, Earnings management in seasoned equity offerings, unpublished manuscript, University of Michigan.

Zweibel, J., 1996, Dynamic capital structure under management entrenchınent, American Economic Review, 86, 1197-1215. 


\section{Table 1}

\section{Characteristics of Sample Firms}

Table I reports the number and percentage of transactions terminated by bidders and others for a sample of 573 unsuccessful takeovers obtained from Mergerstat Review published annually by W.T. Grimm for the period 1982-1991. "Other" includes $32 \%$ of takeover attempts rejected by targets, $11 \%$ mutually rejected, $20 \%$ with no reason given in either Mergerstat Review or The Wall Street Journal Index, $1 \%$ due to lack of financing, $13 \%$ due to a higher bid and $2 \%$ for miscellaneous reasons. Panel B includes the frequency of targets receiving subsequent offer(s) within one year through five years. Panel $\mathrm{C}$ reports the number of targets delisted from CRSP by year for each of the major criteria for delisting.

Panel A: Distribution by identity of terminator

\begin{tabular}{lcc|}
\hline & \# of firms & Percentage \\
\hline Terminated by bidder & 154 & $29 \%$ \\
"Others" & 419 & $71 \%$ \\
Total & 573 & 100 \\
\hline
\end{tabular}

Panel B: Distribution of the number of targets receiving subsequent offer(s) within $j$ years and the number of these offers that were successful

\begin{tabular}{lcccc|}
\hline Received subsequent offer(s) within: & \# of firms & Percentage & \# Successful & Percentage \\
\hline One year & 187 & $33 \%$ & 156 & $27 \%$ \\
Two years & 241 & $42 \%$ & 208 & $36 \%$ \\
Three years & 265 & $46 \%$ & 232 & $40 \%$ \\
Four years & 297 & $52 \%$ & 261 & $45 \%$ \\
Five years & 316 & $55 \%$ & 278 & $48 \%$ \\
\hline
\end{tabular}

Panel C: Distribution of the number of targets delisted from CRSP within $j$ years

\begin{tabular}{|c|c|c|c|c|c|}
\hline \multirow[b]{2}{*}{$\begin{array}{l}\text { Number of } \\
\text { months } 1\end{array}$} & \multicolumn{5}{|c|}{ CRSP Criteria for Delisting } \\
\hline & Takeover & Liquidation & Bankruptcy & $\begin{array}{l}\text { Insufficient } \\
\text { Capital }\end{array}$ & Other Delisting \\
\hline $1-12$ & 156 & 3 & 1 & 4 & 24 \\
\hline $13-24$ & 208 & 7 & 5 & 8 & 32 \\
\hline $25-36$ & 232 & 9 & 5 & 14 & 38 \\
\hline $37-48$ & 261 & 9 & 6 & 16 & 40 \\
\hline $49-60$ & 278 & 10 & 8 & 17 & 47 \\
\hline
\end{tabular}

1 Number of months from the termination of the takeover attempt. 
Table 2

\section{Summary Statistics for Sample Firms}

Panel A reports summary statistics for targets of unsuccessful takeover attempts and transaction characteristics. The sample of unsuccessful takeovers is obtained from Mergerstat Review published annually by W.T. Grimm during the 1982-1991 period. Reported are median, mean, standard deviation and the number of observation (in year -1) of total debt scaled by the book value of assets, industry-adjusted cash flow to book value, industry-adjusted cash flow to sales, market-to-book, and holding period returns of targets minus the holding period returns of the CRSP value-weighted index over the year prior to the announcement of the takeover attempt. Panel B reports top management turnover following unsuccessful takeover attempts. The top manager is defined as the CEO if there is one and the president otherwise. Management changes are identified through comparisons in Standard and Poor's Register of Corporations, Directors, and Executives. Firms are classified based on whether the change in leverage is higher or lower than the median change, and on whether the takeover attempt was hostile or friendly. The percentage of management changes is presented and a difference in means test is also reported.

Panel A: Summary Statistics

\begin{tabular}{lcccc|}
\hline Variable & Median & Mean & Std. dev. & $\mathrm{N}$ \\
\hline Total debt to book value of assets $_{-1}$ & 0.598 & 0.600 & 0.248 & 532 \\
Total debt to book value of assets $_{0}$ & 0.643 & 0.678 & 0.383 & 396 \\
Total debt to book value of assets $_{+1}$ & 0.715 & 0.756 & 0.473 & 328 \\
Total debt to market value of equity $_{-1}$ & 0.287 & 0.394 & 0.289 & 530 \\
Total debt to market value of equity $_{0}$ & 0.305 & 0.442 & 0.446 & 394 \\
Total debt to market value of equity $_{+1}$ & 0.352 & 0.503 & 0.515 & 327 \\
Cash flow to book value $_{-1}$ & 0.119 & 0.109 & 0.130 & 557 \\
Cash flow to sales $_{-1}$ & 0.123 & 0.126 & 0.141 & 555 \\
Industry-adjusted cash flow to book value $_{-1}$ & -0.0015 & -0.0096 & 0.093 & 557 \\
Industry-adjusted cash flow to sales $_{-1}$ & -0.0034 & -0.0018 & 0.072 & 555 \\
Market-to-book $_{-1}$ & 1.21 & 1.61 & 2.43 & 507 \\
Target - CRSP value weighted Index $^{-}$ & -0.0476 & -0.0408 & 0.3108 & 443 \\
& $(0.000)$ & $(0.000)$ & & \\
\hline
\end{tabular}

Panel B: Management Turnover

\begin{tabular}{|lccc|}
\hline \multicolumn{1}{|c}{ Classification } & Mean & p-value & N \\
\hline All sample firms & $32.42 \%$ & & 524 \\
Bidder terminated & $37.56 \%$ & & 134 \\
Rejected by non-bidder & $30.65 \%$ & 0.134 & 390 \\
$\Delta$ in total debt < median $\Delta$ & $30.00 \%$ & & 152 \\
$\Delta$ in total debt > median $\Delta$ & $36.78 \%$ & 0.154 & 146 \\
Takeover attempt is hostile & $44.10 \%$ & & 114 \\
Takeover attempt is friendly & $29.17 \%$ & 0.028 & 410 \\
\hline
\end{tabular}


Table 3

\section{Description of Changes in Total Debt Scaled by the Book Value of Assets}

Table 3 reports summary statistics for changes in total debt scaled by the book value of assets for five years following the termination year for the sample of 573 targets of unsuccessful takeovers obtained from Mergerstat Review published annually by W.T. Grimm for the 1982-1991 period. The median and mean percentage change in book value of debt scaled by the book value of total assets are reported, as well as the number of firms with valid observations. Panels $B$ and $C$ report percentage change in total debt for the hostile and the friendly groups respectively. Non-parametric significance levels for tests in difference in medians are based on Mann-Whitney-Wilcoxon test.

Panel A: Total debt scaled by the book value of assets for the Hostile group

\begin{tabular}{ccccccc|}
\multicolumn{7}{c|}{ From year $\mathrm{i}$ to year i } \\
\cline { 2 - 7 } & \multicolumn{1}{c}{ Median } & -1 to +2 & -1 to +3 & -1 to +4 & -1 to +5 \\
Mean & $12.24 \%$ & $8.97 \%$ & $7.59 \%$ & $7.23 \%$ & $10.99 \%$ \\
$\mathrm{~N}$ & 19.84 & 18.91 & 16.12 & 18.64 & 20.60 \\
\hline
\end{tabular}

Panel B: Total debt scaled by the book value of assets for the Friendly group

From year $i$ to year $j$

\begin{tabular}{ccccccc|} 
& \multicolumn{1}{c}{} & -1 to +2 & -1 to +3 & -1 to +4 & -1 to +5 \\
Median & $2.07 \%^{\mathrm{a}}$ & $2.45 \%^{\mathrm{a}}$ & $4.09 \%^{\mathrm{a}}$ & $4.33 \%^{\mathrm{a}}$ & $4.41 \%^{\mathrm{a}}$ \\
Mean & 11.15 & 11.74 & 11.64 & 12.31 & 11.98 \\
$\mathrm{~N}$ & 238 & $219^{\mathrm{N}}$ & 185 & 156 & 116 \\
\hline
\end{tabular}

a, b, c indicate that the median figures for the hostile and friendly groups are statistically different at the $1 \%$, $5 \%$, and $10 \%$ significance levels respectively. 
Table 4

\section{Corporate Restructuring: Changes in Investment Measures, Number of Employees, Number of SIC Codes, and Frequency of Asset Sales for Targets with a Change in Leverage that is Lower(Higher) than the Median Change}

Summary statistics for capital expenditures scaled by the book value of assets, and research and development expense scaled by the book value of assets for seven years around the failed takeover attempt year, changes in the number of employees scaled by the book value of assets from one year before to one year after the failed takeover attempt year, changes in the number of sic codes from one year before to five years after the failed takeover attempt year, and the frequency of assets sales in the two years after the failed takeover attempt year for the sample of 573 targets of unsuccessful takeovers obtained from Mergerstat Review published by.W.T. Grimm and spans over the 1982-1991 period. Panel A reports the median, mean, and standard deviation of capital expenditures, and research and development expense for targets with a change in total debt that is less than the median change. Panel B reports the same statistics for targets with a change in total debt that is greater than the median change. Percentage changes in capital expenditures scaled by the book value of assets and in research and development expense scaled by the book value of assets for various intervals are reported in Panels $\mathrm{C}$ and D. Panel E reports the mean values and the p-values for the difference in means t-test.

Panel A: Targets with a Change in Leverage that is Lower than the Median Change

Capital expenditures scaled by the book value of assets

\begin{tabular}{lccccccc|}
\hline & Year $(-3)$ & Year $(-2)$ & Year $(-1)$ & Year $(0)$ & Year $(+1)$ & Year $(+2)$ & Year $(+3)$ \\
\hline Median & 0.066 & 0.064 & 0.063 & 0.056 & 0.056 & 0.052 & 0.057 \\
Mean & 0.117 & 0.106 & 0.092 & 0.077 & 0.080 & 0.079 & 0.086 \\
Std. dev. & 0.143 & 0.116 & 0.084 & 0.075 & 0.080 & 0.092 & 0.097 \\
N & 148 & 153 & 152 & 164 & 145 & 122 & 100 \\
\hline
\end{tabular}

Research and development expense scaled by the book value of assets

\begin{tabular}{lccccccc|}
\hline & Year $(-3)$ & Year $(-2)$ & Year $(-1)$ & Year $(0)$ & Year $(+1)$ & Year $(+2)$ & Year $(+3)$ \\
\hline Median & 0.039 & 0.044 & 0.044 & 0.050 & 0.054 & 0.056 & 0.047 \\
Mean & 0.018 & 0.024 & 0.024 & 0.023 & 0.024 & 0.025 & 0.019 \\
Std. dev. & 0.044 & 0.056 & 0.052 & 0.073 & 0.093 & 0.077 & 0.090 \\
N & 59 & 58 & 57 & 58 & 54 & 44 & 38 \\
\hline
\end{tabular}

Panel B: Targets with a Change in Leverage that is higher than the Median Change

Capital expenditures scaled by the book value of assets

\begin{tabular}{lccccccc|}
\hline & Year $(-3)$ & Year $(-2)$ & Year $(-1)$ & Year $(0)$ & Year $(+1)$ & Year $(+2)$ & Year $(+3)$ \\
\hline Median & 0.064 & 0.067 & 0.067 & 0.058 & 0.052 & 0.048 & 0.049 \\
Mean & 0.086 & 0.085 & 0.086 & 0.081 & 0.078 & 0.050 & 0.056 \\
Std. dev. & 0.083 & 0.066 & 0.077 & 0.080 & 0.073 & 0.051 & 0.043 \\
N & 156 & 164 & 169 & 171 & 168 & 159 & 133 \\
\hline
\end{tabular}

Research and Development Expense scaled by the book value of assets

\begin{tabular}{lccccccc|}
\hline & Year $(-3)$ & Year $(-2)$ & Year $(-1)$ & Year $(0)$ & Year $(+1)$ & Year $(+2)$ & Year $(+3)$ \\
\hline Median & 0.010 & 0.011 & 0.011 & 0.008 & 0.007 & 0.007 & 0.010 \\
Mean & 0.029 & 0.032 & 0.027 & 0.026 & 0.022 & 0.028 & 0.032 \\
Std. dev. & 0.047 & 0.083 & 0.055 & 0.034 & 0.031 & 0.048 & 0.058 \\
N & 77 & 82 & 82 & 76 & 79 & 73 & 62 \\
\hline
\end{tabular}


Table 4 (Cont'd)

Panel C: Percentage Change in capital expenditures for Targets with a Change in Leverage that is higher(Lower) than the median Change

$\Delta$ in Debt $<$ median $\Delta$

$\Delta$ in Debt $>$ median $\Delta$

\begin{tabular}{|c|c|c|c|c|c|}
\hline \multicolumn{6}{|c|}{ From year $\mathrm{i}$ to year $\mathrm{j}$} \\
\hline-1 to +1 & -1 to +2 & -1 to +3 & -1 to +1 & -1 to +2 & -1 to +3 \\
\hline$-7.93 \%$ & $-9.22 \%$ & $-10.11 \%$ & $-17.62 \%$ & $-35.36 \%$ & $-27.93 \%^{2}$ \\
\hline 6.91 & 29.62 & 14.52 & $-13.23^{c}$ & -12.16 & -2.87 \\
\hline 44 & 44 & 43 & 39 & 30 & 33 \\
\hline 0.77 & 2.71 & 1.04 & 0.58 & 0.93 & 0.87 \\
\hline 143 & 119 & 97 & 166 & 158 & 132 \\
\hline
\end{tabular}

Panel D: Percentage Change in Research and Development for Targets with a Change in Leverage that is higher(Lower) than the median Change

$\Delta$ in Debt $<$ median $\Delta$

$\Delta$ in Debt $>$ median $\Delta$

From year $\mathrm{i}$ to year $\mathrm{j}$

\begin{tabular}{lccc|cccc} 
& -1 to +1 & -1 to +2 & -1 to +3 & -1 to +1 & -1 to +2 & -1 to +3 \\
Median & $-1.39 \%$ & $9.38 \%$ & $11.51 \%$ & $-8.88 \%^{\mathrm{c}}$ & $-11.84 \%$ & $-8.82 \%$ \\
Mean & $19.04 \mathrm{c}$ & $54.52^{\mathrm{b}}$ & 91.84 & $-9.50^{\mathrm{c}}$ & 9.09 & 13.79 \\
\% positive & 48 & 57 & 63 & 38 & 39 & 45 \\
Std. errors & 0.67 & 1.33 & 3.04 & 0.42 & 0.98 & 1.14 \\
$\mathrm{~N}$ & 44 & 35 & 27 & 61 & 56 & 47 \\
\hline
\end{tabular}

Panel E: Frequency of Asset Sales, Changes in Number of SIC codes and in Number of Employees Scaled by the Book Value of Assets for Targets with a Change in Leverage that is Lower(Higher) than the median Change. (reported values are means)

\section{Characteristic}

$\Delta$ in Debt $<\Delta$ in Debt $>$ median $\Delta$ median $\Delta$ t-test (p-values)

Asset Sales in the two years following the initial

failed takeover attempt

$\Delta$ in the number of sic codes from year -1 to +5

Percentage $\Delta$ in the number of employees from year

$$
-1 \text { to }+1
$$

$$
16.5 \%^{\mathrm{a}}
$$$$
45.4 \%^{\mathrm{a}}
$$

0.156

$-0.645^{a}$

0.002

$\mathrm{a}, \mathrm{b}$, and $\mathrm{c}$ indicate that the estimates are statistically different from zero at the $1 \%, 5 \%$, and $10 \%$ significance levels, respectively. 


\section{Table 5}

\section{Changes in Operating Performance for Targets with a Change in Leverage that is Lower(Higher) than the Median Change}

Table 5 reports median industry-adjusted percentage change in both cash flow to book value and cash flow to sales around the failed takeover attempt year for the sample of $\mathbf{5 7 3}$ targets of unsuccessful takeovers obtained from Mergerstat Review published by W.T. Grimm and spans over the 1982-1991 period. The cash flow to book value and cash flow to sales in year -1 is taken as the benchmark year. Also reported are the percentage change in cash flow scaled by the market value of the firm in year -1. Significance levels are based on a twotailed sign test, reported in parenthesis. Panel A reports the median industry-adjusted percentage change in cash flow to book value and cash flow to sales for targets with a change in total debt that is less than the median change. Panel B reports the same statistics for targets with a change in total debt that is greater than the median change.

\section{Panel A. Change in total debt is less than the medium firm}

\begin{tabular}{|c|c|c|c|c|c|}
\hline & \multicolumn{5}{|c|}{ From year $i$ to year $j$} \\
\hline & -1 to +1 & -1 to +2 & -1 to +3 & -1 to +4 & -1 to +5 \\
\hline $\begin{array}{l}\text { Industry-adjusted percentage change in cash } \\
\text { flow to book value }{ }^{1}\end{array}$ & $\begin{array}{l}-6.58 \% \\
(0.098)\end{array}$ & $\begin{array}{c}-16.69 \% \\
(0.006)\end{array}$ & $\begin{array}{l}-24.42 \% \\
(0.005)\end{array}$ & $\begin{array}{l}-24.52 \% \\
(0.041)\end{array}$ & $\begin{array}{r}-23.08 \% \\
(0.068)\end{array}$ \\
\hline $\begin{array}{l}\text { Industry-adjusted percentage change in cash } \\
\text { flow to sales }\end{array}$ & $\begin{array}{l}-4.09 \% \\
(0.022)\end{array}$ & $\begin{array}{l}-16.04 \% \\
(0.005)\end{array}$ & $\begin{array}{l}-15.05 \% \\
(0.002)\end{array}$ & $\begin{array}{l}-20.19 \% \\
(0.011)\end{array}$ & $\begin{array}{r}-24.70 \% \\
(0.005)\end{array}$ \\
\hline $\begin{array}{l}\text { Percentage change in cash flow scaled by the } \\
\text { market value in year }-1\end{array}$ & $\begin{array}{l}-13.68 \% \\
(0.012)\end{array}$ & $\begin{array}{l}-16.77 \% \\
(0.084)\end{array}$ & $\begin{array}{c}-32.65 \% \\
(0.052)\end{array}$ & $\begin{array}{l}-17.17 \% \\
(0.031)\end{array}$ & $\begin{array}{l}-28.18 \% \\
(0.082)\end{array}$ \\
\hline $\mathbf{N}$ & 144 & 139 & 120 & 96 & 70 \\
\hline
\end{tabular}

Panel B. Change in total debt is greater than the median firm

From year $i$ to year $j$

\begin{tabular}{|c|c|c|c|c|c|}
\hline & \multicolumn{5}{|c|}{ Erom year i to year ] } \\
\hline & -1 to +1 & -1 to +2 & -1 to +3 & -1 to +4 & -1 to +5 \\
\hline $\begin{array}{l}\text { Industry-adjusted percentage change in cash } \\
\text { flow to book value }\end{array}$ & $\begin{array}{l}13.44 \% \\
(0.000)\end{array}$ & $\begin{array}{l}11.86 \% \\
(0.000)\end{array}$ & $\begin{array}{l}13.14 \% \\
(0.003)\end{array}$ & $\begin{array}{l}13.51 \% \\
(0.029)\end{array}$ & $\begin{array}{l}13.19 \% \\
(0.002)\end{array}$ \\
\hline $\begin{array}{l}\text { Industry-adjusted percentage change in cash } \\
\text { flow to sales }\end{array}$ & $\begin{array}{l}16.82 \% \\
(0.000)\end{array}$ & $\begin{array}{l}16.95 \% \\
(0.000)\end{array}$ & $\begin{array}{l}22.01 \% \\
(0.000)\end{array}$ & $\begin{array}{l}15.42 \% \\
(0.000)\end{array}$ & $\begin{array}{l}20.45 \% \\
(0.001)\end{array}$ \\
\hline $\begin{array}{l}\text { Percentage change in cash flow scaled by the } \\
\text { market value in year }-1\end{array}$ & $\begin{array}{l}10.04 \% \\
(0.002)\end{array}$ & $\begin{array}{l}14.86 \% \\
(0.003)\end{array}$ & $\begin{array}{l}25.68 \% \\
(0.000)\end{array}$ & $\begin{array}{l}24.86 \% \\
(0.002)\end{array}$ & $\begin{array}{l}19.57 \% \\
(0.000)\end{array}$ \\
\hline $\mathbf{N}$ & 160 & 152 & 129 & 112 & 100 \\
\hline
\end{tabular}

'Industry-adjusted percentage change is calculated as follows:

$\left[\frac{C F B V_{j}-C F B V_{i}}{\left|C F B V_{i}\right|}\right]-\left[\frac{C F B V I_{j}-C F B V I_{i}}{\left|C F B V I_{i}\right|}\right]$, where $\mathrm{CFBV}_{\mathrm{j}}$ is the cash flow to book value in year

$\mathrm{j}$, and $\mathrm{CFBVI}_{\mathrm{i}}$ is the median cash flow to book value of assets of the firms' two-digit sic code industry in year $\mathrm{i}$. 
Panel C. Change in total debt for the overall sample that survived through year 5

From year $\mathrm{i}$ to year $\mathrm{j}$

\begin{tabular}{|c|c|c|c|c|c|}
\hline & & & & \\
\hline & -1 to +1 & -1 to +2 & -1 to +3 & -1 to +4 & -1 to +5 \\
\hline $\begin{array}{l}\text { Industry-adjusted percentage change in cash } \\
\text { flow to book value' }\end{array}$ & $\begin{array}{r}2.59 \% \\
(0.162)\end{array}$ & $\begin{array}{l}5.72 \% \\
(0.142)\end{array}$ & $\begin{array}{l}-1.96 \% \\
(0.699)\end{array}$ & $\begin{array}{l}2.07 \% \\
(0.939)\end{array}$ & $\begin{array}{l}3.65 \% \\
(0.325)\end{array}$ \\
\hline $\begin{array}{c}\text { Industry-adjusted percentage change in cash } \\
\text { flow to sales }\end{array}$ & $\begin{array}{r}6.90 \% \\
(0.051)\end{array}$ & $\begin{array}{l}11.36 \% \\
(0.029)\end{array}$ & $\begin{array}{l}8.99 \% \\
(0.086)\end{array}$ & $\begin{array}{l}11.14 \% \\
(0.121)\end{array}$ & $\begin{array}{l}2.79 \% \\
(0.693)\end{array}$ \\
\hline $\begin{array}{l}\text { Percentage change in cash flow scaled by the } \\
\text { market value in year }-1\end{array}$ & $\begin{array}{l}0.68 \% \\
(0.697)\end{array}$ & $\begin{array}{l}6.29 \% \\
(0.112)\end{array}$ & $\begin{array}{l}-1.08 \% \\
(0.536)\end{array}$ & $\begin{array}{l}7.79 \% \\
(0.108)\end{array}$ & $\begin{array}{l}6.16 \% \\
(0.093)\end{array}$ \\
\hline $\mathbf{N}$ & 170 & 170 & 170 & 170 & 170 \\
\hline
\end{tabular}

Panel D. Change in total debt is less than the medium firm conditional on surviving through year 5

From year $i$ to year $i$

\begin{tabular}{|c|c|c|c|c|c|}
\hline & \multicolumn{5}{|c|}{ From year 1 to year 1} \\
\hline & -1 to +1 & -1 to +2 & -1 to +3 & -1 to +4 & -1 to +5 \\
\hline $\begin{array}{l}\text { Industry-adjusted percentage change in cash } \\
\text { flow to book value }\end{array}$ & $\begin{array}{l}-8.61 \% \\
(0.129)\end{array}$ & $\begin{array}{l}-5.29 \% \\
(0.625)\end{array}$ & $\begin{array}{c}-30.05 \% \\
(0.002)\end{array}$ & $\begin{array}{l}-28.80 \% \\
(0.014)\end{array}$ & $\begin{array}{l}-23.08 \% \\
(0.068)\end{array}$ \\
\hline $\begin{array}{c}\text { Industry-adjusted percentage change in cash } \\
\text { flow to sales }\end{array}$ & $\begin{array}{l}-3.25 \% \\
(0.159)\end{array}$ & $\begin{array}{c}-12.19 \% \\
(0.172)\end{array}$ & $\begin{array}{c}-14.35 \% \\
(0.038)\end{array}$ & $\begin{array}{l}-19.94 \% \\
(0.047)\end{array}$ & $\begin{array}{l}-24.70 \% \\
(0.005)\end{array}$ \\
\hline $\begin{array}{l}\text { Percentage change in cash flow scaled by the } \\
\text { market value in year -1 }\end{array}$ & $\begin{array}{l}-8.87 \% \\
(0.224)\end{array}$ & $\begin{array}{r}-10.33 \% \\
(0.453)\end{array}$ & $\begin{array}{c}-39.82 \% \\
(0.003)\end{array}$ & $\begin{array}{l}-29.82 \% \\
(0.094)\end{array}$ & $\begin{array}{l}-28.18 \% \\
(0.082)\end{array}$ \\
\hline $\mathbf{N}$ & 70 & 70 & 70 & 70 & 70 \\
\hline
\end{tabular}

Panel E. Change in total debt is greater than the medium firm conditional on surviving through year 5

From year $\mathrm{i}$ to year $\mathrm{j}$

\begin{tabular}{|c|c|c|c|c|c|}
\hline & \multicolumn{5}{|c|}{ From year $i$ to year $j$} \\
\hline & -1 to +1 & -1 to +2 & -1 to +3 & -1 to +4 & -1 to +5 \\
\hline $\begin{array}{c}\text { Industry-adjusted percentage change in cash } \\
\text { flow to book value }{ }^{1}\end{array}$ & $\begin{array}{r}9.16 \% \\
(0.012)\end{array}$ & $\begin{array}{l}13.24 \% \\
(0.016)\end{array}$ & $\begin{array}{l}14.75 \% \\
(0.056)\end{array}$ & $\begin{array}{l}17.26 \% \\
(0.024)\end{array}$ & $\begin{array}{l}13.19 \% \\
(0.002)\end{array}$ \\
\hline $\begin{array}{c}\text { Industry-adjusted percentage change in cash } \\
\text { flow to sales }\end{array}$ & $\begin{array}{l}15.65 \% \\
(0.009)\end{array}$ & $\begin{array}{l}20.67 \% \\
(0.006)\end{array}$ & $\begin{array}{l}22.95 \% \\
(0.004)\end{array}$ & $\begin{array}{l}25.19 \% \\
(0.001)\end{array}$ & $\begin{array}{r}20.45 \% \\
(0.001)\end{array}$ \\
\hline $\begin{array}{l}\text { Percentage change in cash flow scaled by the } \\
\text { market value in year }-1\end{array}$ & $\begin{array}{l}5.02 \% \\
(0.276)\end{array}$ & $\begin{array}{l}12.09 \% \\
(0.004)\end{array}$ & $\begin{array}{l}20.26 \% \\
(0.001)\end{array}$ & $\begin{array}{l}24.86 \% \\
(0.006)\end{array}$ & $\begin{array}{l}19.57 \% \\
(0.000)\end{array}$ \\
\hline $\mathbf{N}$ & 100 & 100 & 100 & 100 & 100 \\
\hline
\end{tabular}


Estimation of the Equation: $\Delta$ in ICFSA $=$ f $(\Delta$ in LEVERAGE, ASSET SALES, $\Delta$ in \# of SIC CODES, CEO TURNOVER, \% $\Delta$ in EMPLOYEES, \% $\Delta$ in CAPITAL EXPENDITURES, HOSTILE-BID, INSIDER OWNERSHIP, BIDDER-TERMINATED)

Estimates of cross-sectional regressions relating changes in operating performance to firm variables for 573 target firms in unsuccessful takeovers for the 1982-1991 period. The dependent variables are the change from year $i$ to year $j$ in industry-adjusted ratio of cash flow to sales. Leverage is measured as the book value of total debt scaled by the book value of total assets. The change in leverage is measured between one year prior to the failed takeover attempt and one year afterwards. Asset Sales is a dummy variable taking the value of 1 if an asset sale occured in the year of or the year after the failed takeover attempt and zero otherwise. Change in the number of SIC codes is measured from one year before to five years following the takeover attempt. CEO turnover a dummy variable taking the value of 1 for a change in the top management and 0 otherwise. The percentage change in the number of employees and in capital expenditures is measured from one year before to two years after the failed takeover attempt. Hostile-bid is a dummy variable taking the value of 1 for hostile takeovers and 0 otherwise. Insider ownership represents the level of insider ownership scaled by the number shares outstanding. Bidder-terminated is a dummy variable taking the value of 1 for non-bidder terminated takeover attempts and 0 for bidder terminated transactions. (t-statistics are in parentheses). ${ }^{1}$

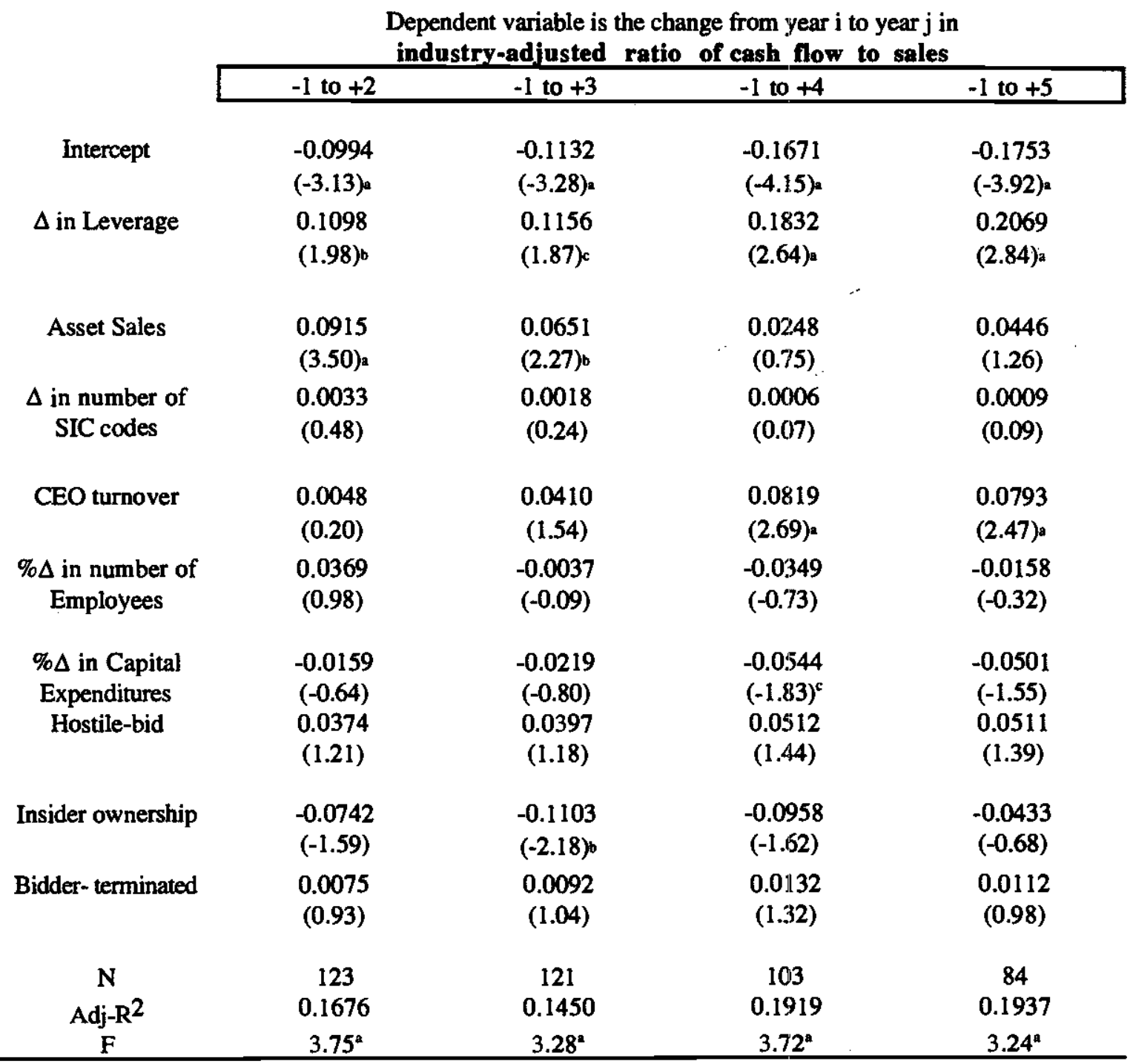

${ }^{1} \mathrm{a}, \mathrm{b}, \mathrm{c}$ indicate that the estimates are statistically different from zero at the $1 \%, 5 \%$ and $10 \%$ significance levels, respectively. 


\section{Estimation of the Equation: $\Delta$ in ICFBV $=f(\Delta$ in LEVERAGE, ASSET SALES, $\Delta$ in \# of SIC CODES, CEO TURNOVER, $\% \Delta$ in EMPLOYEES, \% $\Delta$ in CAPITAL EXPENDITURES, HOSTILE-BID, INSIDER OWNERSHIP, BIDDER-TERMINATED)}

Estimates of cross-sectional regressions relating changes in operating performance to firm variables for 573 target firms in unsuccessful takeovers over the 1982-1991 period. The dependent variables are the change from year $i$ to year $j$ in the industry-adjusted ratio of cash nlow to book value of assets. Leverage is measured as the book value of total debt scaled by the book value of total assets. The change in leverage is measured between one year prior to the failed takeover attempt and one year afterwards. Asset Sales is a dummy variable taking the value of 1 if an asset sale occured in the year of or the year after the failed takeover attempt and zero otherwise. Change in the number of SIC codes is measured from one year before to five years following the takeover attempt. CEO turnover is a dummy variable taking the value of 1 for a change in the top management and 0 otherwise. The percentage change in the number of employees and in capital expenditures is measured from one year before to two years after the failed takeover attempt. Hostile-bid is a dummy variable taking the value of 1 for hostile takeovers and 0 otherwise. Insider ownership represents the level of insider ownership scaled by the number shares outstanding. Bidderterminated is a dummy variable taking the value of 1 for non-bidder terminated takeover attempts and 0 for bidder-terminated transactions. (t-statistics are in parentheses). ${ }^{1}$

Dependent variable is the change from year $i$ to year $j$ in the ratio of iudustry-adjusted cash flow to book value of assets

\begin{tabular}{|c|c|c|c|c|}
\hline & -1 to +2 & -1 to +3 & -1 to +4 & -1 to +5 \\
\hline Intercept & $\begin{array}{l}-0.0631 \\
(-2.84) a\end{array}$ & $\begin{array}{l}-0.0779 \\
(-3.19)_{\mathrm{a}}\end{array}$ & $\begin{array}{l}-0.1209 \\
(-3.82)\end{array}$ & $\begin{array}{l}-0.1365 \\
(-3.66) \mathrm{a}\end{array}$ \\
\hline$\Delta$ in Leverage & $\begin{array}{l}0.0719 \\
(1.86) c\end{array}$ & $\begin{array}{l}0.0856 \\
(1.97) \mathrm{c}\end{array}$ & $\begin{array}{l}0.1368 \\
(2.48) \mathrm{b}\end{array}$ & $\begin{array}{l}0.1716 \\
(2.78)\end{array}$ \\
\hline Asset Sales & $\begin{array}{l}0.0553 \\
(3.11)^{\mathrm{a}}\end{array}$ & $\begin{array}{l}0.0387 \\
(1.97) \mathrm{c}\end{array}$ & $\begin{array}{l}0.0031 \\
(0.12)\end{array}$ & $\begin{array}{l}0.0169 \\
(0.56)\end{array}$ \\
\hline $\begin{array}{l}\Delta \text { in number of } \\
\text { SIC codes }\end{array}$ & $\begin{array}{l}0.0022 \\
(0.46)\end{array}$ & $\begin{array}{c}0.0009 \\
(0.17)\end{array}$ & $\begin{array}{c}-0.0008 \\
(-0.11)\end{array}$ & $\begin{array}{c}0.0003 \\
(0.03)\end{array}$ \\
\hline CEO turnover & $\begin{array}{l}0.0086 \\
(0.52)\end{array}$ & $\begin{array}{l}0.0334 \\
(1.80) c\end{array}$ & $\begin{array}{l}0.0677 \\
(2.84) a\end{array}$ & $\begin{array}{l}0.0720 \\
(2.70) a\end{array}$ \\
\hline $\begin{array}{l}\% \Delta \text { in number of } \\
\text { Employees }\end{array}$ & $\begin{array}{c}0.0272 \\
(1.05)\end{array}$ & $\begin{array}{l}-0.0067 \\
(-0.23)\end{array}$ & $\begin{array}{c}-0.0359 \\
(-0.93)\end{array}$ & $\begin{array}{l}-0.0217 \\
(-0.51)\end{array}$ \\
\hline $\begin{array}{c}\% \Delta \text { in Capital } \\
\text { Expenditures } \\
\text { Hostile-bid }\end{array}$ & $\begin{array}{c}-0.0053 \\
(-0.31) \\
0.0304 \\
(1.44)\end{array}$ & $\begin{array}{c}-0.0104 \\
(-0.55) \\
0.0332 \\
(1.42)\end{array}$ & $\begin{array}{c}-0.0322 \\
(-1.39) \\
0.0415 \\
(1.50)\end{array}$ & $\begin{array}{c}-0.0292 \\
(-1.11) \\
0.0459 \\
(1.50)\end{array}$ \\
\hline Insider-ownership & $\begin{array}{l}-0.0440 \\
(-1.36)\end{array}$ & $\begin{array}{l}-0.0768 \\
(-2.16)^{b}\end{array}$ & $\begin{array}{l}-0.0578 \\
(-1.29)\end{array}$ & $\begin{array}{l}-0.0225 \\
(-0.43)\end{array}$ \\
\hline Bidder-Terminated & $\begin{array}{l}0.0047 \\
(0.83)\end{array}$ & $\begin{array}{c}0.0063 \\
(1.00)\end{array}$ & $\begin{array}{c}0.0103 \\
(1.29)\end{array}$ & $\begin{array}{l}0.0096 \\
(0.99)\end{array}$ \\
\hline$\stackrel{\mathbf{N}}{\text { Adi- } \mathbf{R}^{2}}$ & $\begin{array}{c}124 \\
0.1333\end{array}$ & $\begin{array}{c}122 \\
0.1353\end{array}$ & $\begin{array}{c}104 \\
0.1446\end{array}$ & $\begin{array}{c}85 \\
0.1519\end{array}$ \\
\hline $\begin{array}{c}A u-k- \\
F\end{array}$ & $3.12^{\mathrm{a}}$ & $3.12^{\mathrm{a}}$ & $2.95^{\mathrm{a}}$ & $2.69^{\mathrm{a}}$ \\
\hline
\end{tabular}

' $a, b, c$ indicate that the estimates are statistically different from zero at the $1 \%, 5 \%$ and $10 \%$ significance levels, respectively. 


\section{Table 8}

\section{Relation Between Cumulative Prediction Errors during the Announcement-Termination Period and Change in Leverage}

Table 8 examines the relation between cumulative prediction errors during the announcement-termination period and change in leverage. The dependent variable is the cumulative prediction enrors during the announcement-termination period. It is calculated over 5 days before the announcement and 5 days after the termination of the takeover attempt. Tests are conducted for a sample of $\mathbf{3 0 0}$ different firms with valid leverage data on CompuStat. Leverage is measured as the book value of total debt scaled by the book value of total assets. The change in leverage is measured between one year prior to the failed takeover attempt and one year afterwards. CEO turnover a dummy variable taking the value of 1 for a change in the top management and 0 otherwise. Bidder-terminated is a dummy variable taking the value of 1 for non-bidder terminated takeover attempts and $\mathbf{0}$ for bidder terminated transactions. Hostile-bid is a dummy variable taking the value of 1 for hostile takeovers and 0 otherwise. Subsequent is a dummy variable taking the value of 1 if the target firm receives a subsequent offer in the following five years, and 0 otherwise. The $t$ statistics in parenthesis are based on the White adjusted standard errors.

Dependent variable is the cumulative prediction errors during the announcement-termination period

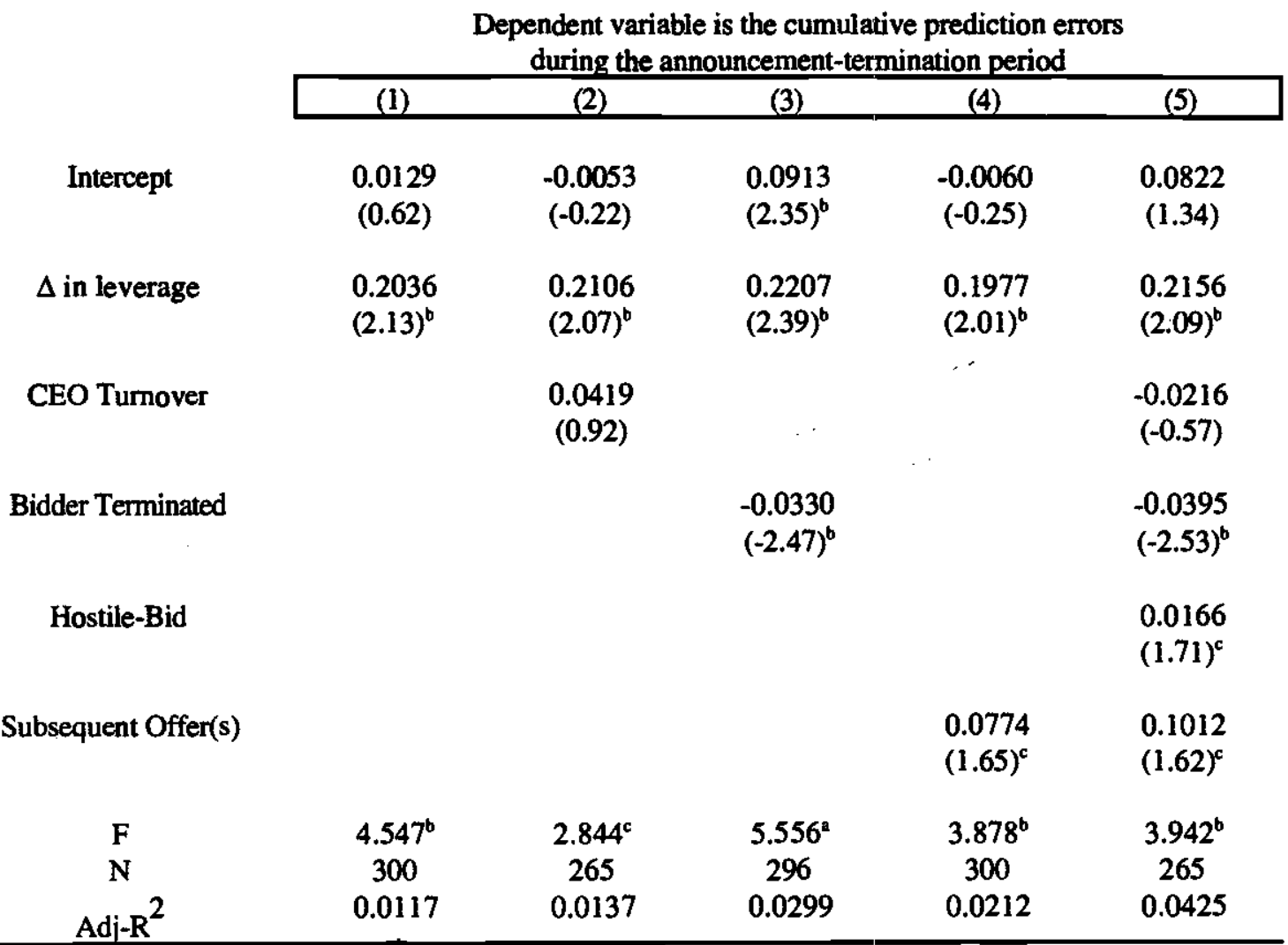

${ }^{1} \mathrm{a}, \mathrm{b}, \mathrm{c}$ indicate that the estimates are statistically different from zero at the $1 \%, 5 \%$ and $10 \%$ significance levels, respectively. 
Table 9

\section{Holding Period Returns for Targets and their Matching Firms During the Five Years Following the Termination of the Failed Takeover Attempt}

Holding-period returns (HPR) for 437 target firms in unsuccessful takeover attempts obtained from Mergerstat Review published by W.T. Grimm from 1982-1991 period. Holding-period returns are computed using the CRSP-listed closing price as the purchase price. The difference in holding period returns is calculated as $\Sigma\left(1+R_{i t}\right)-\Sigma\left(1+R_{j t}\right)$, where $R_{i t}$ is the holding period return starting the month after the termination month of the takeover attempt until the earlier of the delisting date or the five-year anniversary of the takeover attempt, $\mathbf{R}_{\mathrm{jt}}$ is the holding period return on a matching portfolio. Each target firm is matched with a characteristic benchmarks portfolio of the same size quintile, the same book-tomarket quintile, and the same momentum quintile in the year prior to the event. Percent negative is the percentage of negative returns.

\begin{tabular}{|c|c|c|c|c|}
\hline $\begin{array}{c}\text { First } \\
\text { quartile }\end{array}$ & Median & Mean & $\begin{array}{l}\text { Third } \\
\text { quartile }\end{array}$ & $\begin{array}{c}\text { Percent } \\
\text { negative }\end{array}$ \\
\hline
\end{tabular}

Panel A: All target firms $(\mathrm{N}=437)$

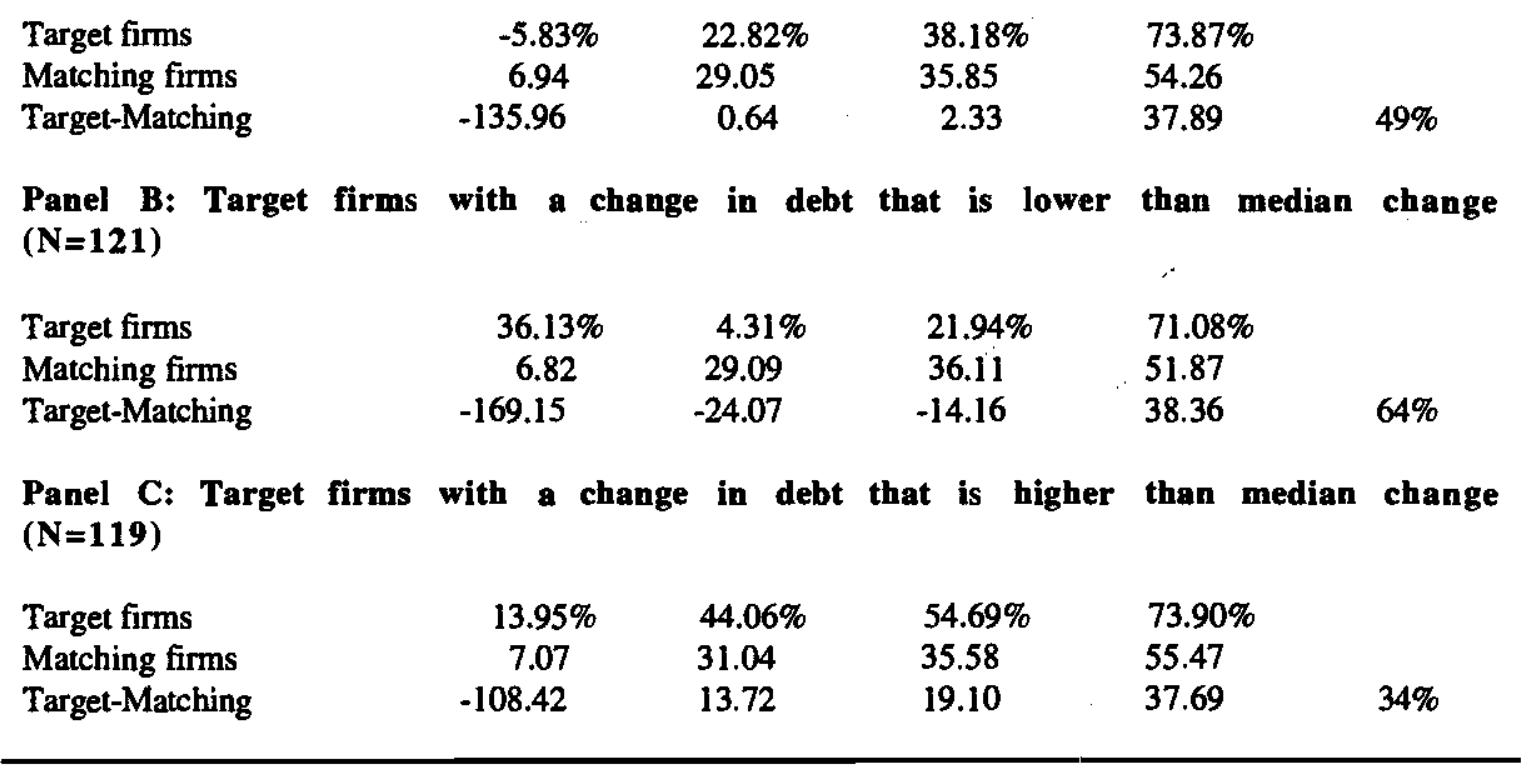


Table 10

Times-Series Analysis of Percentage Monthly Portfolio Returns Post Failed Takeover Attempt for Targets and Their Matched Firms from February, 1982 to December, 1994

Average monthly portfolio returns for 437 target firms in unsuccessful takeover and monthly returns for the portfolio of their matching firms from the period February 1982 to December 1994. Portfolio monthly returns are equally weighted averages of firm monthly returns. Target firms are added to their portfolio in the month following the termination of the takeover attempt and kept in the portfolio for 60 months or when the firm ceases trading. The matching firm is added to, and removed from the matching-firm portfolio when its target firm is added or removed. Sample firms in unsuccessful takeover attempts are obtained from Mergerstat Review published by W.T. Grimm from 1982-1991 period. Returns are computed for calendar months using CRSP daily returns. Significance levels are based on t-tests.

Panel A

Mean Monthly

Returns(\%)

(1) Portfolio of target firms with above-median-change

$1.652 \%$

(2) Portfolio of matching firms for target firms

$1.136 \% \mathrm{e}$

(3) Portfolio return to target firms minus the portfolio return to their matching firms

$+0.516 \% \mathrm{c}$

Panel B

Mean Monthly

Returns(\%)

(1) Portfolio of target firms with below-median-change

$0.949 \%$

(2) Portfolio of matching firms for target firms

$1.140 \% \mathrm{e}$

(3) Portfolio return to target firms minus the portfolio return to

$-0.191 \%$ their matching firms

$\mathrm{c}, \mathrm{d}$, and $\mathrm{e}$ indicate that the estimates are statistically different from zero at the $10 \%, 5 \%$ and $1 \%$ levels respectively. 